\title{
A study on desktop publishing and digital applications used in publicity and advertisement strategies in tourism in Turkey ${ }^{1}$
}

Gülay Bulgan², Yasemin Duran ${ }^{3}$

\begin{abstract}
Tourism is one of the important sectors which play a significant role in supporting economic development in Turkey just as in many other countries. Turkey is a country which has made vigorous efforts in order to develop tourism sector. Within this context, Turkey is continuing to develop fast by concentrating on areas such as investment, publicity, marketing in tourism. It is seen that various publicity and advertisement campaigns are being carried out in Turkey in order to publicize the country and make it a brand in tourism. Distances between countries have decreased as a result of the globalization and technological developments in the recent years, which has led countries to tend towards new types of tourism in order to gain advantages and new markets. Therefore, countries have started to attach importance to publicity and advertisement campaigns. This is the main cause of the macro level competition being experienced between countries in tourism sector. The countries which aim to increase their market shares in this competitive environment have concentrated on publicity and advertisement campaigns. The advertising activities used by Turkey in tourism are greatly diversified thanks to the different methods and means employed. This study seeks to bring to light the activity performance of these practices by evaluating the new strategies of publicity and advertisement campaigns used in tourism sector in Turkey. This study includes domestic and foreign literature reviews. In addition, the activity report for 2015 of the Ministry of Culture and Tourism, the data provided by State Planning Organization and Turkish Statistical Institute were studied. The study contains the outstanding examples of new publicity activities which have developed as a result of the technological developments witnessed in Turkey in the recent years.
\end{abstract}

Keywords: Turkey, tourism sector, advertisement, publicity.

To cite this article: Bulgan, G. Duran, Y. (2017). A study on desktop publishing and digital applications used in publicity and advertisement strategies in tourism in Turkey. Journal of Tourism Theory and Research, 3(1), 43-51. DOI: 10.24288/jttr.296821

\footnotetext{
${ }^{1}$ This study is presented at 2nd International Conference on Tourism: Theory, Current Issues and Research, İstanbul, Turkey

${ }^{2}$ Suleyman Demirel University, Turkey, gulaybulgan@sdu.edu.tr

${ }^{3}$ Suleyman Demirel University, Turkey, yaseminduran@sdu.edu.tr
} 


\section{Introduction}

Tourism is a sector which adds value to a country by increasing inflow of foreign currency, accelerating economic development through employment generation by exploiting a country's natural, historical and archeological heritage (Bahar and Kozak, 2012:712; Roney, 2011:73). In addition, tourism is one of the leading sectors which brings many countries closer to each other on the international platform. Turkey has not only attached importance to tourism but also made great efforts to keep the sector strong and profitable. The country has been making great progress in this sector by improving its investment, publicity, marketing and training the staff. Within this ongoing process, Turkey is continuing to improve itself by concentrating on publicity and advertisement activities (Demir and Demir:2015: 162).

The publicity concept has a very broad scope ranging from social structure to organization; from economic structure to culture and to traditions (Rızaoğlu, 2004:30). Publicity is a scientific job and based on creation just as science is. Publicity activities are of such a nature that it cannot be included into any formulas, except for some general principles. No matter what their types are, all publicity activities aim to do similar things such as attracting attention, informing, convincing and creating a favorable impression on people's minds, rendering a change in behaviours and attitudes towards the desired target (Tolungüç, 1999:14-83). Turkey has been trying to create the right image for itself through its efforts to attach greater importance to publicity in the recent years. Publicity and advertisement activities are of great significance when creating the right image for a country.

Advertising may be defined as an integrated component of the free market economy which persuades consumers to continue with a certain trademark, helps them to make comparisons between them and again help them to grasp the differences and novelties trademarks have as supply of products continue increasing (Ünüvar; 2008). According to the American Union, advertising is the presentation of a product, service or idea to the mass media through advertising agencies sponsored by a known company or person (Odabaş1, 1995:64, Tikveş 2005:194, Ünüvar, 2008:56).
It may be said that advertising and publicity activities have many functions. According to Tolungüç promoting a product, transferring information, creating an image, preparing the customer for the sale or making them purchase are among the most important of these functions (Tolungüç; 1999:110). The applications which prepare these publicity and advertising varieties for the above functions are newspapers, magazines, brochures, letters, exhibitions, television, radio and other media that have been introduced into our lives recently. Five decisions must clearly be determined while choosing advertising applications. These applications are determining the aim of the advertisement, forming the budget of the advertisement, creating the slogan and choosing the advertising channel (Arslan; 2007:16; Kozak, 2006:200-201). According to Dae, Hwang and Fesemaier's Tourism Advertising Effectiveness Model, success of advertising application strategies has a great impact on the number of visitors a destination can host (Dae et al., 2005:42).

Figure 1. Tourism advertising effectiveness model

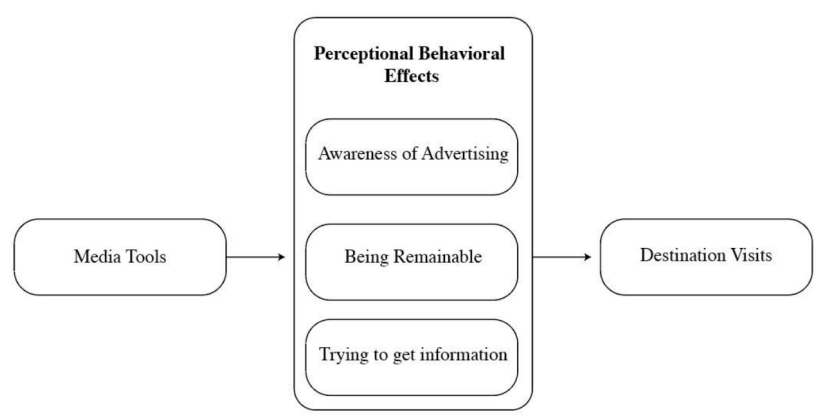

Source: Dae, et al., 2005: 42-49.

Just as written messages are important in tourism advertising, visual messages do attract attention. According to Book and Schick, a good photograph which is placed on an advertisement text add plausibility and reliability to the applied advertisement (Book and Schick, 1998:90). They tried to emphasize the significance of a photograph used in an advertisement especially in terms of permanence. A photograph which is directly related to the subject of the advertisement must both meet a consumer's expectations and create a perception that the consumer will have the particular lifestyle that he or she is dreaming of. Therefore, all advertising and publicity images are of extreme importance.

The Ministry of Culture and Tourism has 
participated in some international fairs and carried out advertising and public relations campaigns in more than 80 countries in order to promote the cultural and touristic values of Turkey and to show its touristic richness and superiority of its tourism products. In addition to these, special projects and cultural activities are performed in order to support them. According to statistics the published by the General Directorate of Promotion, the budget of this directorate increased from 43 million Turkish liras in 2000 to 153 million Turkish liras in 2010, which amounts to a more than 3.5 fold increase (kulturbakanligi.gov.tr/er.tar. 2016).

Figure 2. The budget of general directorate of promotion by year.

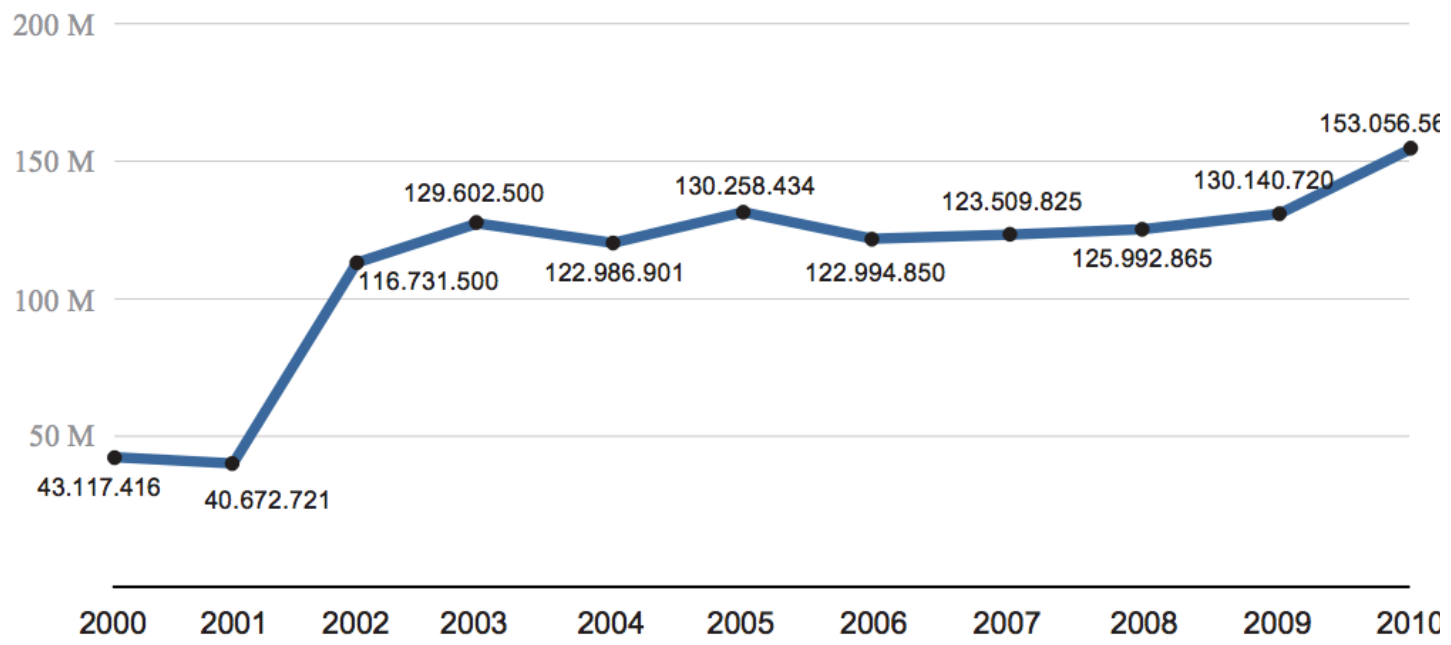

Source: The Budget of General Directorate of Promotion, The Ministry of Culture and Tourism.

When we study the budget allocated and the promotional activities of the Ministry of Culture and Tourism, it is seen that advertising is divided into three categories as "Conventional Advertising", "Digital Advertising (social media, digital media, travel media) "Integrated Advertising, a combination of digital and conventional advertising". It is known that strategic cooperation projects in this field are also materialized in addition to these. Turkey, which was home to more than 30 civilizations and is distinguished by its history, geography, cultural and touristic values, has been promoted with the concept of "Turkey Home of..." since 2014. This concept continued by renewing itself in 2015. Besides, sub campaigns were held in order to support the concept (The Booklet of Activity published by the Ministry of Culture and Tourism, 2015:226).

\section{Research method}

The purpose of this research is to bring to light the activity performance of these practices by evaluating the new strategies of publicity and advertisement campaigns used in tourism sector in Turkey. This study includes domestic and foreign literature reviews. In addition, the activity report for 2015 of the Ministry of
Culture and Tourism, the data provided by State Planning Organization and Turkish Statistical Institute were studied. The study contains the outstanding examples of new publicity activities which have developed as a result of the technological developments witnessed in Turkey in the recent years.

\section{Conventional advertising}

The conventional advertising includes notably introductory films, spots and digital boards broadcast on popular television and radio channels in foreign countries and all the other visuals published in popular newspapers and magazines. While vehicle wrapping is especially preferred at airports, theatres, shopping malls, undergrounds and open areas, magazine and television visuals and images are also employed in order to influence plane passengers. These applications include printed materials such as posters, catalogues, brochures, billboards, megalights and vehicle wrapping, which are also known as desktop publishing.

Conventional advertising has been conducted with the concept of "Turkey Home of..." under the roof of a global advertising campaign by the General 
Directorate of Promotion, the Ministry of Culture and Tourism since 2014. All the advertising visuals used in this concept were taken by world-famous photographers, Mark Edward Harris, Hazel Thompson, Robert M. Knight and Steve McCurry, who is known for his famous "Afghan girl" photograph. A global advertising campaign was conducted in order to create a favorable image for Turkey. The fact that works of world famous photograph artists were included in the concept was an important factor on its being globally successful (The Booklet of Activity, The Ministry of Culture and Tourism, 2015:226).

One of the most important applications which attract attention and which is frequently used in desktop publishing is posters. When we have a look at the sample works, it is clearly seen that an important content analysis with regard to the tourism posters employed for the promotion of Turkey between the years 2010 and 2015. The data concerning the promotion strategy followed by Turkey in poster production over the past five years are given in table 1 . When we have a look at table, the numerical distribution of the promotion posters which represent the universe of the study and the common themes used are seen together (Güdekli et al., 2015: 953).

Table 1. The theme numbers of the desktop poster applications by year

\begin{tabular}{|c|c|c|c|c|c|}
\hline \multirow[t]{2}{*}{ Year } & \multirow{2}{*}{$\begin{array}{l}\text { Number } \\
\text { of } \\
\text { Posters }\end{array}$} & \multicolumn{4}{|c|}{ Theme } \\
\hline & & Nature & Cultural & Architectural & Historical \\
\hline 2010 & 29 & 10 & 7 & 6 & 7 \\
\hline 2011 & 15 & 6 & 2 & 5 & 8 \\
\hline 2012 & 11 & 6 & 6 & 8 & 8 \\
\hline 2013 & 7 & 6 & 1 & 1 & 2 \\
\hline 2014 & 71 & 15 & 31 & 23 & 27 \\
\hline 2015 & 75 & 28 & 11 & 12 & 11 \\
\hline
\end{tabular}

Source: Güdekli et al., 2015:953.

Picture 1 shows the poster works among the printed materials in 2010 and target market information. Picture 1 clearly shows that the promotion applications employed after 2010 represent a universe of concept. This table was formed by analyzing the relation between the indicator, signifier and signified and creation of slogans. During the process following this analysis, the posters were analyzed descriptively by discussing in terms of literal and connotative meaning.

Picture 1. Poster works and target markets used among the printed materials in 2010

The Target Market
England, Sweden, Denmark,
Finland, Germany, The
Netherlands, Belgium, Poland,
Switzerland, Austria.
The United States of America,
Canada, Mexico, Spain, Italy,
France, Bosnia Herzegovina,
Bulgaria, Serbia, Macedonia,
India, Japan.

Russia, Ukraine, Turkic Republics.

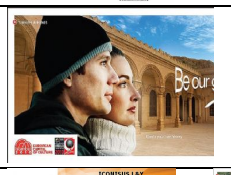

The Alternative Campaign

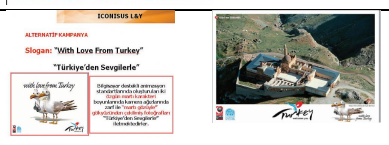

The United Arab Emirates, Pakistan, Saudi Arabia, Egypt, Iran, Syria, Israel.

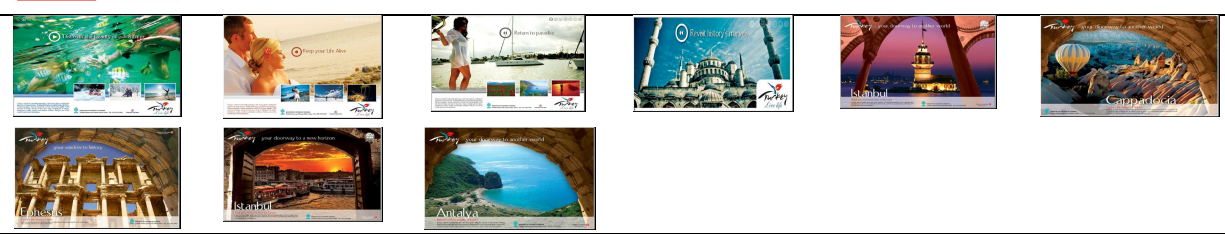

Source: Turizmde Bu Sabah, Digital Tourism Magazine. 
Picture 2. Poster works included in the printed materials in 2011

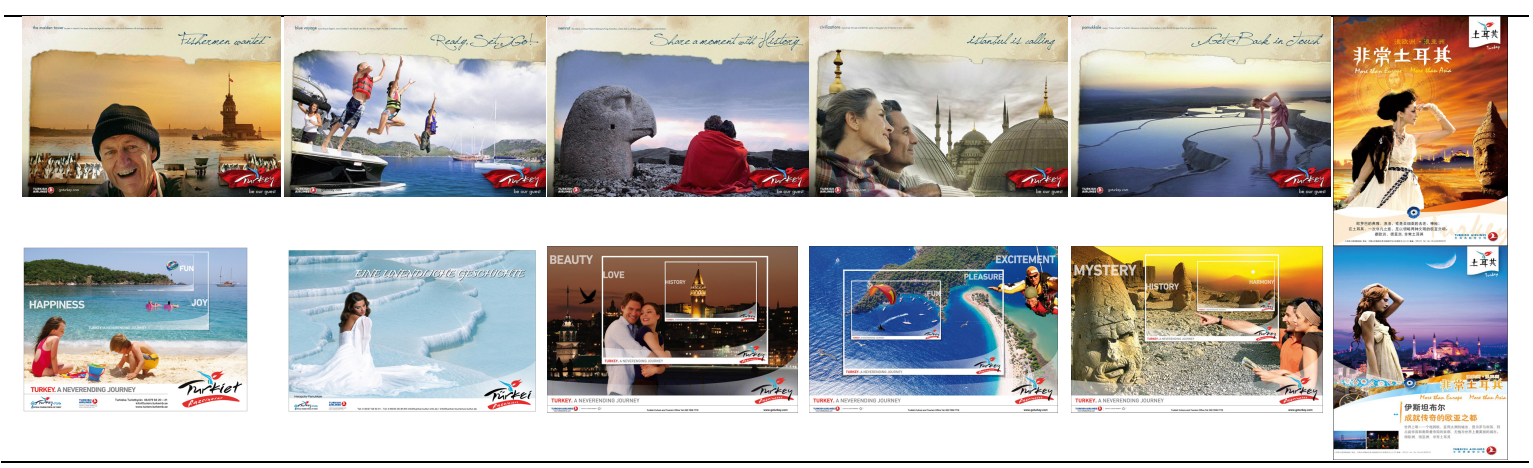

Source: Turizmde Güncel magazine, 2011.

Picture 3. Poster works from the printed materials used in 2012
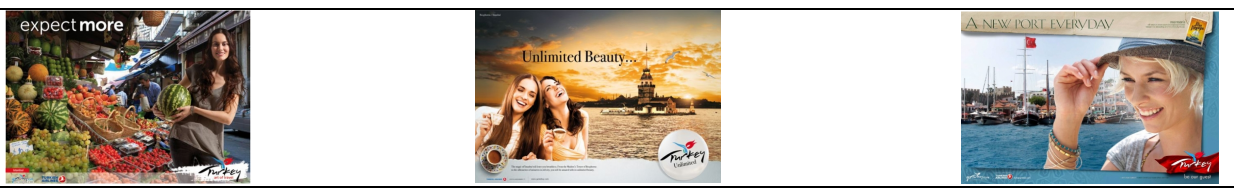

Source: Turizmde Güncel magazine, 2012.

Picture 4. Poster designs used on the printed materials in 2013-2015

\begin{tabular}{llll}
\hline \multicolumn{2}{c}{2013} & 2014 & 2015 \\
\hline
\end{tabular}

Source: The Booklet of Activity, The Ministry of Culture and Tourism, 2013.

Picture 2 shows the poster works used among the printed materials in 2011. Campaigns intended for the whole world, not for a determined target market, were held as of 2011.

Picture 3 shows poster works from the printed materials used in 2012. There is no information on a single country being aimed at in the poster works produced in 2012. It is seen that a general publicity campaign aimed at the whole world was held. Picture 4 shows poster works included in the printed materials used in 2013. It is seen that shorter slogans were used on posters and more general expressions were used to reach the target in the year 2013.

Picture 4 shows poster designs used on the printed materials in 2014. What is striking about the year 2014 is the fact all the posters designed included the slogan "Turkey Home of..." Picture 4 shows poster designs used on the printed materials in 2015. It is seen that the posters designs created in 2015 contain the slogan “Turkey Home of ..." just as the ones produced in 2014.
The conventional advertising conducted after 2010 indicate that desktop advertising activities were conducted in accordance with the target market's demands. One can see that slogans and concept in harmony with the cultural structure of countries were on trend. For example, when we have a look at the slogans of the campaigns in 2010, a variety of slogans strike the eye. "Feeling Good, Feel the Mystery, Be Part of It, Meeting Points Of Continents" The posters on which these slogans are used and alternative mascot and city mottos prove that the concepts continuously change in accordance with the theme and the city where the posters are used. Compared to 2010, while 2011 has relatively fewer variety of mottos, the campaign language is more universal. Printed materials which aimed to reach all the world were popular in 2011. The slogans used in 2011 contain words such as "Happiness, Joy, Fun, Beauty, Love, Excitement, Pleasure, Mystery, History" were predominant and it is seen that city promotions and alternative statements were of importance now. As for the years 2012 and 2013, one can see that two slogans 
stand out among the others, which are "Expect Home" and "Turkey Unlimited". The slogan "Home of Turkey" seem to have gained popularity in the years 2014 and 2015.

The themes used on the promotion posters mainly contained the historical sites in Turkey and İstanbul and Turkish traditions and customs were emphasized. Although the campaigns aimed at different countries, the languages of the texts were mostly English. The slogans preferred were inserted in words and phrases such as "Calling, Ready, Home of..." to be more emphatic in accordance with the place, region, city, cultural heritage etc. which are intended to get into the subconscious of the consumer. In intersemiotics, the worry to send intersemiotic messages is of utmost importance. Every photograph and slogan used on posters has a story and a background within this context. Every design produced contains different ideas and messages. Therefore, it is seen that the conventional advertising campaigns are of great importance for the promotion of Turkey.

\section{Digital advertising}

Publicity campaigns in tourism and travel industries over the world tend to shift towards digital advertising, which is gradually becoming more common and this trend continued to extend in 2015 thanks to the perception management strategy of the campaign "Turkey Home of..." launched in 2014 on a global scale. The tourism campaigns which make use of digital and social media have been seen more often recently and had great success in the years $2014-2015$.

The campaign was held with the concept of "home" in mind which evokes warm, sincere emotions in many foreign cultures and which can reflect all the richness and beauties of Turkey, which has been home to tens of civilizations throughout history and is distinguished from the rival countries with her cultural, artistic and touristic values. Because Turkey is a country which has been home to myriad elements of culture, history and nature from baklava to Turkish coffee, from Gobeklitepe to Troy, Ayder Plateau to the blues of the Aegean and Mediterranean. Therefore, Turkey deserves to be promoted in the most effective, successful and right way (The Ministry of Culture, the Activity Report 2015:228). Digital Media is divided into three categories, which are social media, travel media, digital media.

\subsection{Social media}

Social media is a concept which has dimensions such as media, internet user and technology. When we have a look at the social media, we see applications such as Facebook, Twitter, Google, Instagram, Youtube, Pinterest, Linkedin, Vine etc. With the campaigns held on these digital platforms, Turkey's cultural and touristic values can be publicized faster all over the world. The Ministry of Culture and Tourism has been able to contact people faster and directly by launching campaigns in which many visuals and videos promoting the cultural values of Turkey were used.

The Facebook page titled "Turkey Home" was chosen "The Best Trademark" by Skift (A media company which does studies on tourism in Newyork); in addition, the twitter page ranked first on the list of "1000 Travel Destinations" in Rise Global sector. The Global Image Campaign of Turkey, as seen in Figure 2 , with its nearly 6 million followers rose to the second place among other tourism promotion campaigns as of end of December, 2015. Therefore, Turkey has gained important experience with regard to "creating one's own media" concept, which has been on trend in country/destination promotion (The Activity Report, The ministry of Culture and Tourism, 2015:229).

\subsection{Travel media}

Travel is defined as "journey or voyage" by the Turkish Language Association (tdk.gov.tr, 2016). Travel is the movement of a person from a point to another overland, by sea or air. With the introduction of the internet into our lives, travelers formed various travel media platforms. As a result, various travel platforms have emerged followed by educated internet users who are interested in travelling and make travel plans.

TripAdvisor with over 40 million visualizations and over 5 million visitors and Expedia with over 20 million viewing and over 3 million single visitors are among the most popular holiday/tourism sites in the world and Matador Network (a social media influencer supported website which creates original content for trademark destinations) have been influential platforms in Turkey's promotion campaigns. 
Figure 3. The number of the followers of Turkey's social and digital media accounts as of January 4, 2016 and comparison with that of other countries

\begin{tabular}{|c|c|c|c|c|c|c|c|c|c|c|c|}
\hline $4 / 1 / 2016$ & & Facebook & witter & Google + & istagram & a ube & iterest & nkedln & Vine & $\begin{array}{c}\text { Total } \\
\text { Followers }\end{array}$ & Ranking \\
\hline Australia & $\geq$ & $6,624,389$ & 284,112 & $2,460,449$ & $2,027,827$ & 24,898 & 8,500 & 35,209 & 8,105 & $11,473,489$ & 1 \\
\hline Turkey & HOME & $4,447,075$ & 795,405 & 398,783 & 223,048 & 14,793 & 4,100 & 13,931 & 15,500 & $5,912,635$ & 2 \\
\hline USA & USA & $5,216,955$ & 41,238 & 166,079 & 21,684 & 13,050 & 0 & 0 & 0 & $5,459,006$ & 3 \\
\hline Mexico & $\equiv$ & $4,565,414$ & 129,699 & 311,058 & 66 & 12,914 & 3,700 & 0 & 0 & $5,022,851$ & 4 \\
\hline United Kingdom & aㅡㄹ & $3,077,546$ & 243,374 & 140,795 & 181,126 & 5,878 & 0 & 0 & 0 & $3,648,719$ & 5 \\
\hline Greece & & 618,011 & 58,090 & $2,626,350$ & 67,310 & 8,571 & 7,000 & 0 & 0 & $3,385,332$ & 6 \\
\hline Dubai & $=$ & $2,886,540$ & 59,611 & 0 & 88,791 & 26,173 & 0 & 0 & 0 & $3,061,115$ & 7 \\
\hline Spain & 요 & $1,583,378$ & 190,495 & 197 & 82,155 & 9,799 & 0 & 0 & 0 & $1,866,024$ & 8 \\
\hline Hong Kong & 4 & $1,590,478$ & 78,995 & 0 & 55,359 & 18,961 & 0 & 0 & 0 & $1,743,793$ & 9 \\
\hline Croatia & 2 & $1,459,719$ & 41,479 & 10,388 & 56,540 & 4,777 & 0 & 0 & 0 & $1,572,903$ & 10 \\
\hline Canada & $\Leftrightarrow$ & 352,311 & 203,080 & 575,110 & 372,800 & 12,618 & 5,000 & 0 & 0 & $1,520,919$ & 11 \\
\hline Singapore & 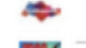 & $1,386,975$ & 38,333 & 0 & 53,651 & 6,942 & 0 & 0 & 0 & $1,485,901$ & 12 \\
\hline Thailand & E & $1,053,276$ & 65,994 & 343,560 & 0 & 16,708 & 0 & 0 & 0 & $1,479,538$ & 13 \\
\hline France & 3 & $1,233,385$ & 12,528 & 677 & 0 & 491 & 2,000 & 7,281 & 0 & $1,256,362$ & 14 \\
\hline Italy & $\mathscr{I I}$ & 346,728 & 78,917 & 202,190 & 14,606 & 3,955 & 3,900 & 0 & 0 & 650,296 & 15 \\
\hline
\end{tabular}

Source: The Ministry of Culture and Tourism, The Booklet of Activity, 2015.

\subsection{Digital media}

Thanks to AdWords and Banner (an institutional communication element prepared in the form of an advertisement and which appears in different sizes mostly above the title or on other parts of a website) advertising campaigns, Turkey was seen to have gone up the list of travel search. Turkish advertising in tourism has been preferred by the internet users from among more than 300 million websites, and internet users were addressed in their own language. In addition, campaigns in native languages were held through Yahoo (more than 250 million visitors and over 2 billion viewing per day) and Maktoob, which is a popular portal in Arab-Gulf countries, all of which provided a considerable access and viewing (The Booklet of Activity, The Ministry of Culture and Tourism, 2015: 235).

The campaign "Turkey Home" continued to add variety to its advertising activities during 2015 with projects such as "Journey Through Turkey), "Welcome Home", "Feels Like Home", "Home is where... is", "Masters At Work", "Adventure in Turkey". In order to raise the number of followers and enhance the interaction of social media channels, in addition to
GastroHunt, which was first held on the theme of gastronomy last year, Fashion Hunt and TurquoiseHunt projects were also materialized with the participation of persons with a high number of followers in 2015 and millions of people were reached through the contents produced.

\subsection{Strategic cooperation projects}

Intensive effort was made so that Turkey's promotional campaigns could be held in cooperation with cultural, artistic and sports organizations. The followings are the activities done within this contex in 2015:

- The Euroleague Organization: Turkey took part in this organization as a global partner for the first time, which is regarded as the most prestigous basketball league in Europe and which is folowed by millions of spectators and a lot of promotional campaigns both desktop and digital were performed in the "Final 4" organization

- Eurosport International Editorial Television and Web Advertising Project: Various advertising and promotional films in which well-known sportsmen of Turkey acted were shot in İstanbul, Cappadocia, 
Antalya, Erzurum, Rize, Alaçatı and Belek and were televised on Eurosport, which is the sports channel with the highest number spectators in the world, broadcasts in 21 languages in 54 countries.

- Advertising Contract with Alba Berlin Basketball Team: Several advertising activities were held with ALBA Berlin Basketball Team, which plays in German Beko Basketball Division and which has a capacity of 10.000 spectators per game and 3000 combined tickets per year.

- Extreme Sailing Series: All advertising elements, whether printed or digital were included in "Extreme Sailing Series", the 9th season of which was held in 2015, and other great organizations such as America Cup and Olympics.

\section{Conclusion}

Money spent on desktop and digital advertising in tourism is gradually increasing on a global scale. While there is a decrease in the number of printed materials in desktop advertising, advertising done through social media has been on the increase. The reason for this may be the fact there has been a tremendous increase in mobile applications and mobile users. Therefore, while mobile advertising expenditures has increased to a great extent, desktop applications remain to be important. The prediction reports that E-Marketer prepared for the digital advertising sector in the USA seem to verify this fact. According to these reports, while 32.4 billion dollars were spent on desktop advertising, 4.3 billion dollars were spent on mobile advertising. In addition, the total money spent on desktop advertising in the USA rose to 35.3 billion dollars in 2014, which is the peak value. The volume which mobile advertising is expected to reach is 11.7 billion dollars. An insignificant drop was seen in the figures after 2014. The desktop advertising dropped to 35.2 billion dollars in 2015 and 34.4 billion dollars in 2016 and it is predicted to drop to 32.5 billion dollars in 2017. The decrease in desktop expenditures was attributed to the increase in mobile advertising spending. The mobile advertising spending in the USA increased to 11.7 billion dollars in 2014, 16.6 billion dollars in 2015 and 22.2 billion dollars in 2016 and it is predicted to rise to 27.9 billion dollars in 2017.

According to the advertising spending figures in social media, while a total of 266 million dollars were spent on mobile Twitter advertising in 2013, the money spent on desktop advertising was 218 million dollars. Mobile Twitter advertising spending went up to 627 million dollars in 2015. When Facebook is in question in social media web, it is seen that firms attach more importance to desktop in digital advertising spending. In 2013, while desktop Facebook advertising spending was 1.7 billion dollars, the figure spent on mobile advertising was 1.1 billion dollars. As for the year 2015, desktop Facebook advertising spending approximated 2 billion dollars. Mobile facebook advertising spending was 1.9 billion dollars during the same period. When we have a look at the US market estimates, it is understood that a different viewpoint is being presented to the world with regard to the future of desktop advertising, which the digital advertising often discusses (e-Marketer, 2016).

The data obtained in this study done on the desktop publication and digital applications used in promotion and advertising strategies in tourism in Turkey show that more institutional expressions are used in the slogans on the printed materials from 2010 on. It is seen that the printed materials used in promotional activities from 2010 to 2016 aimed at the whole world rather than individual countries by printing a single slogan on different materials. Another important finding determined in this study is the fact that the slogans on the printed materials used from 2010 to 2016 gradually tended to become shorter, more influential. This change, which was observed in Turkey's advertising and promotional activities between 2010 and 2016, was determined to have positively contributed to Turkey's among foreign people by creating a more positive image. According to the data obtained from advertising and promotional activities in the USA, although the predicted figures in social media advertising indicate a fast progress, it is understood that desktop advertising will remain to be important. This holds true for all the other world countries, including Turkey. Therefore, when we take into consideration the problematic process Turkey has experienced in the recent years, it is predicted that the new advertising strategies Turkey has been using will have a positive impact on Turkish tourism.

\section{References}

Arslan, A. (2007). Türkiye'nin Tanıtım Harcamalarının Dış Turizm Talebine Etkileri, Balıkesir Üniversitesi Sosyal 
Bilimler Enstitüsü Turizm İşletmeciliği ve Otelcilik Anabilim Dalı, Balıkesir, Yüksek Lisans Tezi.

Bahar, O. \& Kozak, M. (2012). Turizm ve Rekabet, Ankara: Detay Yayıncilık.

Book, Albert C. C. \& Dennis, S. (1998). Reklamcılıkta Metin ve Taslağın Ilkeleri, Çev:

Dae, Y. K., Yeong, H. H. \& Daniel R., F. (2005). “Modeling Tourism Advertising Effectiveness", Journal of Travel Search, 4: 42-49.

Demir. M. \& Demir. Ş. Ş. (2015). Otel Işsletmelerinde Yenilik Yönetimi Illkeler ve Örnekler, Ankara: Detay Yayincilik.

Güdekli, A, Ehtiyar R, Güzel Ö. \& Ersoy, A. (2015). Turizme Yönelik Tanıtım Afişlerinde İmge olarak Kadın: Göstergebilimsel Bir Analiz, 16. Ulusal Turizm Kongresi 12-14 Kasım, Çanakale.

Kozak, N. (2006). Turizm Pazarlaması, Ankara: Detay Yayıncilik.

Odabaş1, Y. (1995). Pazarlama İletişimi, Eskişsehir: Anadolu Üniversitesi Yayınlar1.

Rızaoğlu, B. (2004). Turizmde Tanıtma, Ankara: Detay Yayıncilik.

Roney, S. A. (2011). Turizm Bir Sistemin Analizi, Ankara: Detay Yayıncilik.

Tikveş, Ö. (2015). Halkla İlişkiler\&Reklamcılık, İstanbul: Beta Basım Yayım Dağıtım.

Tolungüç, A. (2000). Turizmde Tanıtım ve Reklam, Ankara: Mediacat Yayınları.

Ünüvar, Ş. (2008). Konaklama İşletmeleri Ă̆ırlıklı
Turizmde Reklam Kampanyaları, Konya: Çizgi Kitapevi.

T.C. Kültür ve Turizm Bakanlığı, Strateji Geliştirme Başkanlığı, İdare Faaliyet Raporu, 2015, http://sgb.kulturturizm.gov.tr/Eklenti/44841, bakanligim iz-2015-yili-idare-faaliyet-raporu.pdf?0 Erişim tarihi:12 Temmuz 2016

Turizmdebusabah, İşte Türkiye'yi 2010'da dünyaya tanitacak afişs ve sloganlar, http://www.turizmdebusabah.com/haber-foto/isteturkiyeyi-2010da-dunyaya-tanitacak-afis-ve-sloganlar49685-1.html Erişim Tarihi: 04 Ağustos 2016

TurizmGüncel.com, 2011 Türkiye tanıtımında Anadolu parlatılacak. İşte afişler, http://turizmguncel.com/haber/2011-turkiyetanitiminda-anadolu-parlatilacak-iste-afislerh4475.html Erişim tarihi: 09.A ğustos. 2016

T.C. Kültür ve Turizm Bakanlığı, Strateji Geliştirme Başkanlığı, İdare Faaliyet Raporu, 2013, http://sgb.kulturturizm.gov.tr/Eklenti/23748,2013-idarefaaliyet-raporu-ana-metin-25042014.pdf?0 (Erişim tarihi: 10.Haziran.2016).

T.C. Kültür ve Turizm Bakanlığı, Strateji Geliştirme Başkanlığı, İdare Faaliyet Raporu, 2014, http://sgb.kulturturizm.gov.tr/Eklenti/40020,2014-idarefaaliyet-raporu-13042015pdf.pdf?0 Erişim tarihi: 19.Ağustos. 2016

When Will Desktop Ad Spending Peak? As mobile gains ground, spending on desktop banners and search are poised for decline, http://www.emarketer.com/Article/Will-Desktop-AdSpending-Peak/1009959 Erişim tarihi: 09.Ağustos.2016 